\title{
Properties of R Plasmid R772 and the Corresponding Pilus-specific Phage PR772
}

\author{
By J. N. COETZEE, G. LECATSAS, W. F. COETZEE \\ Department of Microbiology, University of Pretoria, and \\ MRC Unit for Microbial Genetics, Pretoria, South Africa \\ AND R. W. HEDGES \\ Department of Bacteriology, Royal Postgraduate Medical School, London
}

(Received 1 August 1978)

$\mathrm{R}$ plasmid R772 was isolated from a strain of Proteus mirabilis and is a self-transmissible P-1 incompatibility group plasmid having a molecular weight of about $27 \times 10^{6}$. It renders bacterial hosts resistant to kanamycin. Phage PR772 was isolated as a phage dependent on the presence of R772 in bacterial hosts. It is hexagonal-shaped with a diameter of $53 \mathrm{~nm}$, has a thick inner membrane and no tail. Vaguely defined appendages are sometimes apparent at some vertices and the phage possesses double-stranded DNA. The DNA has a guanine plus cytosine molar content of $48 \%$. The phage is sensitive to chloroform and has a buoyant density of $1.26 \mathrm{~g} \mathrm{~cm}^{-3}$. These observations suggested that the inner membrane of the phage could contain lipid. Phage PR772 differs in morphology from the doublestranded DNA plasmid-specific phages PR4 and PRR1 which adsorb to tips and sides, respectively, of sex pili coded for by P-1 incompatibility group plasmids. Phage PR772 formed clear plaques which varied in diameter. Serologically, phages PR772 and PR4 are possibly related though very distantly, but the two phages have identical host ranges. Phage PR772 adsorbed by one of its apices to tips of sex pili coded for by plasmid R772 in Escherichia coli. It also formed plaques on Salmonella typhimurium, Proteus morganii and Providence strains harbouring this plasmid as well as strains of $E$. coli carrying plasmids of incompatibility groups $\mathrm{N}$ or $\mathrm{W}$. The phage produced areas of partial clearing on lawns of $P$. mirabilis PM5006 harbouring plasmid R772, the P-1 incompatibility group plasmid RP4, the W group plasmid RSa or the $\mathrm{N}$ group plasmid N3, and on lawns of Providence strain P29 carrying plasmid RP4.

\section{INTRODUCTION}

Hedges (1975) described a series of plasmids conferring resistance to kanamycin, all derived from strains of Proteus mirabilis from a hospital in Boston, U.S.A. R plasmid $\mathrm{R} 772$, a member of this series, was found to be self-transmissible at frequencies of $5 \times 10^{-3}$ per donor cell and able to mobilize Mor174, a non self-transmissible Proteus morganii bacteriocinogenic plasmid (Williams, 1977; Coetzee et al., 1977). It can also mobilize the $P$. mirabilis chromosome (Coetzee, 1978). Because the incompatibility group of R772 had not been determined and because the relatively high frequency of conjugal transfer made it feasible to attempt to isolate a phage specific for the transfer apparatus of the plasmid (Meynell \& Lawn, 1968; Khatoon et al., 1972), we decided to do both simultaneously. A specific phage was isolated and $\mathrm{R} 772$ proved to be a P-1 incompatibility group plasmid. Properties of the system are described in this paper 
Table 1. Bacteria, bacteriophages and plasmids

Bacteria
Proteus mirabilis
PM5006
PM5006nal-r
Proteus morganii
2815nal-r
Providence
P29nal-r

Salmonella typhimurium
LT2 trpA8
Escherichia coli
J53
J53-1
J62
J62-1
J62str-r
Pseudomonas phaseolicola
HB10Y

Bacteriophages

$\phi 6$

PRR1

PR4

Plasmids

R772

$\mathrm{R} 1 d r d 19$

R64drd11

R144drd3

ColIdrd 16

R391

R392

R397

N3

R378

RP4

R751

R68.45

P-lac

$\mathrm{RSa}$

C, K, S, Su

T, PMX mutant. A

Properties*

$27 \times 10^{6}$ dalton. $\mathrm{K}$

$\mathrm{A}, \mathrm{C}, \mathrm{K}, \mathrm{S}, \mathrm{Su}$

A, T

K, T

Colicin I producing

K

K

K

$\mathrm{S}, \mathrm{Su}, \mathrm{T}$

A, C, S, Sp, Su, T

$\mathrm{A}, \mathrm{K}, \mathrm{T}$

$\mathrm{Tp}$

A, K, T

$\mathrm{C}, \mathrm{K}, \mathrm{S}, \mathrm{Su}$
Properties*

Host for generalized transducing phage $5006 \mathrm{M}$.

Spontaneous Nal mutant

NCTC strain 2815. Host for generalized transducing phage $\mathrm{M}$. Spontaneous Nal mutant

Providence strain NCTC 9211. Biogroup A. Recipient for phage PL25. Spontaneous Nal

Tryptophan A auxotroph of strain LT2

$\mathrm{F}^{-}$pro, met mutant of $E$. coli $\mathrm{K} 12$

Spontaneous Nal mutant

$\mathrm{F}^{-}$pro, his, trp mutant of $E$. coli $\mathrm{K} 12$

Spontaneous Nal mutant

Spontaneous $\mathbf{S}$ mutant

Host for phage $\phi 6$

Properties
Buoyant density $1.27 \mathrm{~g} \mathrm{~cm}^{-3}$
RNA phage. Adsorbs to sides of pili coded for
by P-1 group plasmids
Lipid-containing double-stranded DNA phage.
Adsorbs to tips of pili coded for by $\mathrm{N}, \mathrm{P}$
and W group plasmids
Incompatibility group

Circular DNA approx.

P-1

Lactose utilization, $\mathrm{Su}$
FII

I

I

I

J

?J

N

N

P-1

P-1

P-1

A-C

W
Reference

Coetzee \& Smit (1970);

Coetzee (unpublished)

Coetzee (1974)

Coetzee (1966); Coetzee

et al. (1966)

Coetzee et al. (1966)

N. Datta

Clowes \& Hayes (1968)

Clowes \& Hayes (1968)

Clowes \& Hayes (1968)

Coetzee et al. (1972)

Coetzee (unpublished)

Vidaver et al. (1973); supplied by W. Snipes

Reference/source

Vidaver et al. (1973);

supplied by W. Snipes

Olsen \& Thomas (1973); supplied by D. E. Bradley

Stanisich (1974); supplied by D. E. Bradley

Reference

Hedges (1975);

this paper and unpublished Meynell \& Cooke (1969)

Meynell \& Datta (1967)

N. Datta

Coetzee et al. (1972)

Coetzee et al. (1972)

Coetzee et al. (1972)

Hedges (1972)

Coetzee et al. (1972)

Datta et al. (1971)

Jobanputra \& Datta (1974)

Haas \& Holloway (1976)

Hedges (1975)

Hedges \& Datta (1971)

* Symbols designate resistance to: A, ampicillin; C, chloramphenicol; K, kanamycin; Nal, nalidixic acid; PMX, polymixin; S, streptomycin; Sp, spectinomycin; Su, sulphonamide; $\mathrm{T}$, tetracycline; Tp, trimethoprim.

\section{METHODS}

Bacteria, bacteriophages and plasmids. These are listed in Table 1.

Media and antibiotics. Nutrient broth was Oxoid no. 2, code CM67; nutrient agar was the same broth solidified with $1.2 \%$ (w/v) Difco agar. MacConkey agar was from Difco. NBY media (Sands et al., 1974) were used for the growth of Pseudomonas phaseolicola, the host of phage $\phi 6$. The incubation temperature was $37^{\circ} \mathrm{C}$, apart from work with phage $\phi 6$ where it was $25^{\circ} \mathrm{C}$. Ampicillin, chloramphenicol, tetracycline, nalidixic acid, streptomycin, kanamycin and polymixin B were used at $30 \mu \mathrm{g} \mathrm{ml}^{-1}$. Streptomycin was also used at $1 \mathrm{mg} \mathrm{ml}^{-1}$. 
Production of phage lysates and general phage techniques. The methods described by Adams (1956) and Coetzee (1974) were used.

Phage buffer. TNTC buffer (Olsen et al., 1974) was used; this consisted of $0.01 \mathrm{M}-\mathrm{Tris}, 1 \cdot 17 \mathrm{M}-\mathrm{NaCl}$, $0.5 \%(\mathrm{w} / \mathrm{v})$ Tryptone and $0.001 \mathrm{M}-\mathrm{CaCl}_{2}$, at $\mathrm{pH} 7$.

Isolation of bacteriophage specific for bacteria harbouring plasmid $\mathrm{R} 772$. The method of Meynell \& Lawn (1968) was used. Briefly, attempts were made to enrich the phage population of a sample of sewage by overnight incubation with either PM5006nal-r(R772) or J62-1(R772). The mixture was then filtered through a $0.45 \mu \mathrm{m}$ pore-size Millipore membrane and drops of the filtrate were spotted on lawns of the other organism and both the wild-type parent organisms lacking the plasmid. Five daily samples from the main Pretoria sewage works and three specimens from the sewage of a Pretoria hospital were tested independently.

Phage adsorption. A sample of exponential phase bacteria in broth $\left(3 \mathrm{ml}\right.$, about $5 \times 10^{8}$ viable organisms $\mathrm{ml}^{-1}$ ) was mixed with $0.1 \mathrm{ml}$ of a phage suspension $\left[1 \times 10^{9}\right.$ plaque-forming units (p.f.u.) $\left.\mathrm{ml}^{-1}\right]$ and incubated for $20 \mathrm{~min}$. The bacteria were then deposited by centrifugation at $8000 \mathrm{~g}$ for $10 \mathrm{~min}$ and the supernatant was titrated for unadsorbed phage. As a control, an isogenic strain which lacked the plasmid was substituted for the test strain and processed simultaneously. The percentage of phage adsorbed was calculated from the difference in plaque-forming titres between the test and control suspensions.

Multiplication of phage in liquid medium. A sample of exponential phase bacteria in broth (1 $\mathrm{ml}, 10^{7}$ to $10^{8}$ bacteria $\left.\mathrm{ml}^{-1}\right)$ was diluted $1: 3$ in pre-warmed broth and $0.1 \mathrm{ml}$ of a phage PR772 suspension $\left(5 \times 10^{9}\right.$ p.f.u. $\mathrm{ml}^{-1}$ ) was added. Phage suspension was also added to $3 \mathrm{ml}$ broth as a control. The mixtures were incubated overnight, then centrifuged and the phage titre of the supernatant was determined.

Preparation of phage antiserum. Eight injections of phage PR772 $\left(1.0 \mathrm{ml}, 5 \times 10^{10}\right.$ p.f.u. $\left.\mathrm{ml}^{-1}\right)$ were given intravenously at $3 \mathrm{~d}$ intervals to each of three rabbits. After resting the animals for $10 \mathrm{~d}$, blood was collected and the serum was heated at $56^{\circ} \mathrm{C}$ for $30 \mathrm{~min}$ to inactivate complement. The serum was then absorbed with J62-1(R772).

Purification of phage. Cell debris was removed from $250 \mathrm{ml}$ PR772 lysate by centrifugation at $10000 \mathrm{~g}$ for $15 \mathrm{~min}$ at $4{ }^{\circ} \mathrm{C}$ in a Sorvall SS34 rotor. Phage was then sedimented by centrifugation at $90000 \mathrm{~g}$ for $2 \mathrm{~h}$ at $4{ }^{\circ} \mathrm{C}$, using an SW27 rotor. Pellets were resuspended overnight in TNTC buffer and then centrifuged at $10000 \mathrm{~g}$ for $15 \mathrm{~min}$ at $4{ }^{\circ} \mathrm{C}$. $\mathrm{CsCl}$ gradients were prepared by adding $\mathrm{CsCl}$ to a mean density of $1.3 \mathrm{~g} \mathrm{~cm}{ }^{-3}$, as determined refractometrically. Centrifugation was carried out at $90000 \mathrm{~g}$ in a SW65 rotor for $47 \mathrm{~h}$ at $4{ }^{\circ} \mathrm{C}$. An intense band was observed in each gradient. The bands were collected through the sides of the tubes by means of syringes and were pooled. The pooled materials were centrifuged in separate $\mathrm{CsCl}$ gradients as above and yielded one well-defined band. The band was collected as above and dialysed against TNTC buffer. The phage yield was $5 \times 10^{12}$ p.f.u. $\mathrm{ml}^{-1}$.

For PR4, the same procedure was followed. Phage $\phi 6$ was prepared using Pseudomonas phaseolicola strain HB10Y as host bacterium.

Nucleic acid melting. Phage PR772 nucleic acid was extracted as described by Olsen et al. (1974). A melting profile was obtained by the method of Mandel \& Marmur (1968).

Conjugal transfer of plasmids. Methods were as described by Datta et al. (1971) and Datta \& Hedges (1972). Conjugation mixtures were incubated for $1 \mathrm{~h}$.

Compatibility of $R$ factors and transfer from 'doubles'. These methods were described by Coetzee et al. (1972).

Electron microscopy. When necessary, specimens were concentrated by centrifugation. A small portion of the pellet was taken up in distilled water and the suspension was mixed with an equal volume of $3 \%$ (w/v) phosphotungstic acid. A drop of this mixture was then applied to a Formvar-carbon coated grid, allowed to dry and examined in a Philips EM300 electron microscope at an instrumental magnification of 42000 .

\section{RESULTS}

\section{Interspecific plasmid transfer and compatibility properties}

Plasmid R772 was transferred between strains of $E$. coli $\mathrm{K} 12$ with an efficiency of abour $1 \times 10^{-3}$ per donor which is similar to that shown by P-1 incompatibility group plasmids like RP4 and R751 (Hedges \& Jacob, 1974).

When R772 was transferred to a strain carrying R751 there was efficient elimination of the trimethoprim resistance caused by $\mathrm{R} 751$. When the reciprocal transfer was made, however, elimination of kanamycin resistance was usually delayed, and if strains showing both resistances were grown in drug-free medium and then plated on agar, most colonies had lost trimethoprim resistance. However, prolonged growth in_medium with trimethoprim led eventually to the loss of kanamycin resistance. 

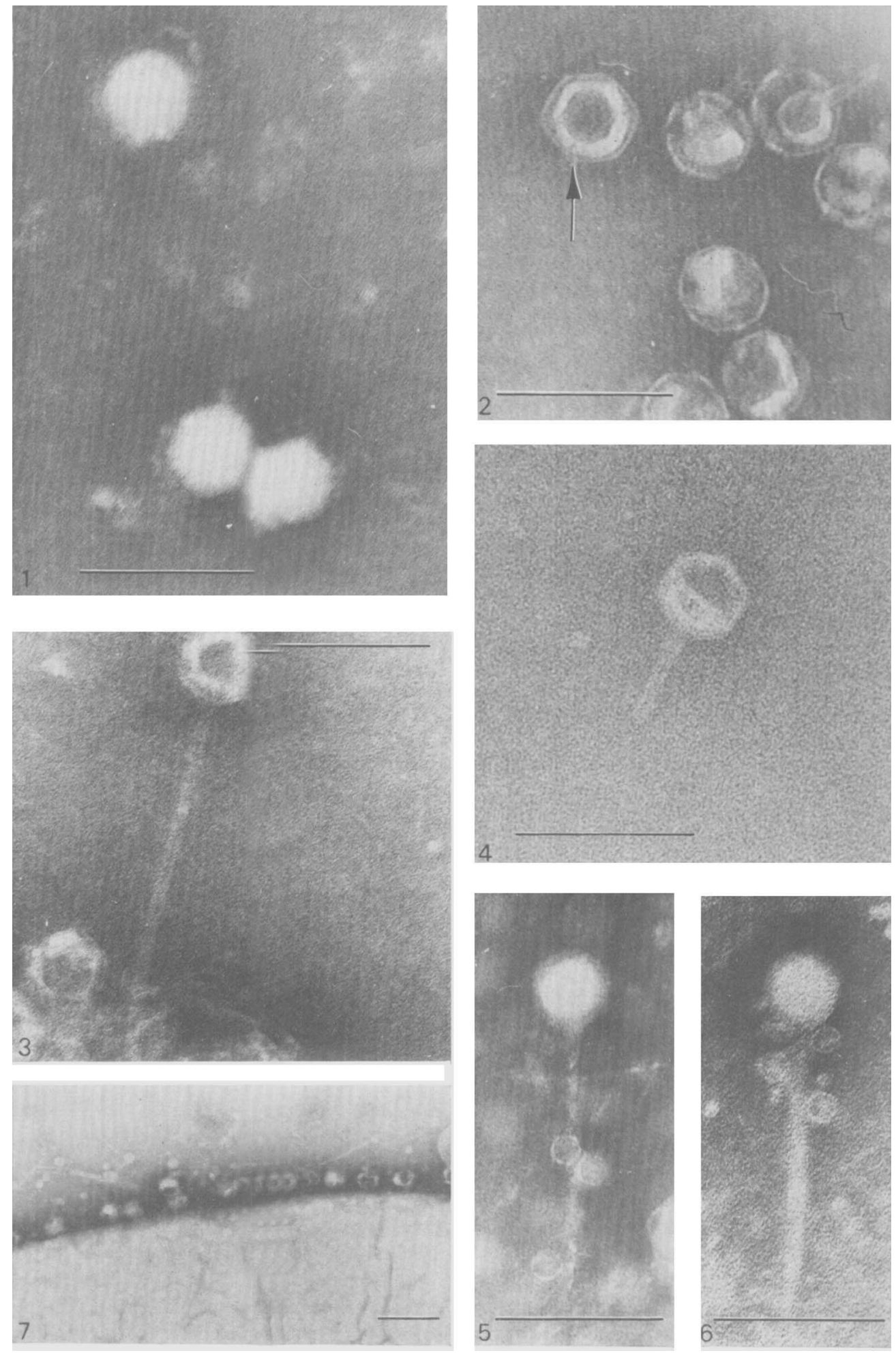


\section{Isolation of an R772-dependent bacteriophage}

From only one of the sewage samples (from the main sewage works) incubated with PM5006nal-r (R772), a phage was isolated which plated on J62-1(R772) and not on J62-1 or PM5006nal-r. The phage also did not form plaques on the organism ostensibly used for phage enrichment - PM5006nul-r(R772) (see below). The phage was named PR772 and was propagated on $\mathrm{J} 62-1(\mathrm{R} 772)$.

\section{Properties of phage PR772}

Plaque morphology. Plaques on lawns of all hosts (see below) were always clear and varied from 1 to $3 \mathrm{~mm}$ in diameter. Single plaque isolates of small or large plaques again produced plaques within this diameter range.

Chloroform sensitivity. A phage suspension was gently shaken with $0 \cdot 1$ vol. chloroform for $10 \mathrm{~min}$. A control suspension, to which nothing had been added, was also shaken. After $15 \mathrm{~min}$ to allow phase separation, the plaque-forming titre of the two suspensions was determined. The chloroform treatment reduced the titre by $99 \%$.

Morphology. Electron microscopy of negatively-stained preparations showed that the phage particle had a clear hexagonal form suggesting icosahedral symmetry. Some intact particles showed poorly-defined appendages at some vertices (Fig. 1) which could represent the structures reported by Olsen et al. (1974) for phage PRD1. The diameter was $53 \pm 3 \mathrm{~nm}$ and there was no tail (Fig. 1). An internal layer was visible in presumed 'empty' particles and this core had a diameter of $36 \pm 2.2 \mathrm{~nm}$ (Fig. 2). The appearance of the particles inactivated with chloroform suggested that the internal layer had collapsed, although untreated suspensions also contained some particles with a partially disrupted internal component. Chloroform treatment had no effect on the external layer of the phage particle. About $10 \%$ of particles in preparations with the phage added to suspensions of J62-1(R772) were attached to the end of rigid, hollow tubular rods with lengths of 40 to $400 \mathrm{~nm}$ (Figs $3,4)$. The appearance of these free complexes did not allow a decision as to whether the phage was attached to a particular end. The rods had a diameter of $9 \pm 0.75 \mathrm{~nm}$ and were attached to one of the corners of the icosahedral-shaped phage capsid. Phage PR772 was never seen attached to the sides of the rods. The rods resembled the bacterial pili coded for by P-I incompatibility group plasmids (Bradley, 1974, 1975).

Serology. The three rabbits produced antisera with phage PR 772 inactivation constants (K) of $6.76,4.86$ and $8.32 \mathrm{~min}^{-1}$. The plaque-forming titre of phage PR4 was neutralized at $\mathrm{K}$ values of $0.68,0.20$ and $0.34 \mathrm{~min}^{-1}$ by the three sera, respectively. These are very low values for PR4 and the phages may possibly be distantly related serologically.

Host range. Phage PR772 formed plaques on strains of E. coli, Salmonella typhimurium, $P$. morganii and Providence which harboured plasmid R772. It also lytically infected strains of $E$. coli carrying plasmids of incompatibility groups P-1, N or W (Table 2) but had no

Bar markers represent $100 \mathrm{~nm}$ in Figs 1 to $6,200 \mathrm{~nm}$ in Fig. 7.

All preparations were stained with $3 \%(\mathrm{w} / \mathrm{v})$ phosphotungstic acid.

Fig. 1. Typical appearance of phage PR772. Note the vaguely defined appendages at some vertices on the lower particles.

Fig. 2. 'Empty' phage particle (arrowed) showing the inner layer.

Fig. 3. Phage particle attached to a long pilus fragment [J62-1(R772) preparation]. Note the length of the pilus relative to the phage diameter.

Fig. 4. Phage particle attached to a short piece of pilus [J62-1(R772) preparation].

Figs 5, 6. Preparations of J62-1(R772) showing attachment of phage PRR1 to the sides of pili and phage PR772 to the tips of the same structures.

Fig. 7. Phage PR772 adsorbed to a cell of strain PM5006nal-r(R772). Closely packed phage particles cover the cell surface. 


\section{Table 2. Host range of phages}

Drops of phage suspension (titre $5 \times 10^{9}$ p.f.u. $\mathrm{ml}^{-1}$ ) were spotted on lawns of organisms contained in top-layer agar.

$\begin{array}{lcccc}\text { Host strain } & \begin{array}{c}\text { Plasmid } \\ \text { incompatibility } \\ \text { group }\end{array} & \text { PR772 } & \text { PR4 } & \text { PRR1 } \\ \text { J62-1(R772) } & \text { P-1 } & + & + & + \\ \text { P29nal- } r \text { (R772) } & \text { P-1 } & + & + & + \\ \text { 2815nal-r(R772) } & \text { P-1 } & + & + & + \\ \text { LT2(R772) } & \text { P-1 } & + & + & + \\ \text { J62(RP4) } & \text { P-1 } & + & + & + \\ \text { J62(R68.45) } & \text { P-1 } & + & + & + \\ \text { J53-1(RSa) } & \text { W } & + & + & - \\ \text { J53(N3) } & \text { N } & + & + & - \\ \text { J62-1 } & - & - & - & - \\ \text { J53-1 } & - & - & - & - \\ \text { P29nal-r } & - & - & - & - \\ \text { 2815nal-r } & - & - & - & - \\ & +, \text { Plaque formation; } & -, \text { no visible action. } & \end{array}$

Table 3. Adsorption and multiplication of phage PR772 on different bacterial strains

\begin{tabular}{|c|c|c|c|c|c|c|c|c|c|c|c|}
\hline \multirow[b]{3}{*}{ Host strain } & \multirow{3}{*}{$\begin{array}{c}\text { Resident } \\
\text { plasmid }\end{array}$} & \multirow{3}{*}{$\begin{array}{l}\text { Plasmid } \\
\text { incom- } \\
\text { patibility } \\
\text { group }\end{array}$} & \multicolumn{8}{|c|}{ Phage action } & \\
\hline & & & \multicolumn{3}{|c|}{ Plaque formation } & \multicolumn{3}{|c|}{ Adsorption $(\%)$} & \multicolumn{3}{|c|}{ Multiplication } \\
\hline & & & PR772 & PR4 & PRR1 & PR772 & PR4 & PRR1 & PR772 & PR4 & PRR1 \\
\hline PM5006 & . & . & - & - & - & $<4$ & $<4$ & $<4$ & - & - & - \\
\hline P29nal-r & . & & - & - & - & $<4$ & $<4$ & $<4$ & - & - & - \\
\hline PM5006nal-r & R772 & P-1 & $*$ & $*$ & $*$ & $3-6$ & $3-6$ & $3-6$ & - & - & - \\
\hline PM5006 & RP4 & P-1 & $*$ & $*$ & $*$ & $3-6$ & $3-6$ & $3-6$ & - & - & - \\
\hline P29nal-r & $\mathrm{R} 772$ & P-1 & + & + & + & 81 & 72 & 52 & + & + & + \\
\hline P29nal-r & RP4 & P-1 & $*$ & $*$ & $*$ & $3-6$ & $3-6$ & $3-6$ & - & - & - \\
\hline
\end{tabular}

* No plaque formation but areas of partial clearing; + , plaque formation or increase in titre of about $5 \times 10^{2}$ p.f.u. $\mathrm{ml}^{-1} ;-$, no action or no increase in titre detected.

Table 4. Transfer frequency of plasmid $\mathrm{R} 772$

\begin{tabular}{lccc}
\multicolumn{1}{c}{ Donor } & Recipient & Selection* & $\begin{array}{c}\text { Frequency of transfer } \\
\text { (per donor cell) }\end{array}$ \\
J62-1(R772) & PM5006 & T K & $1 \times 10^{-3}$ \\
PM5006nal-r(R772) & J62str-r & S K & $8 \times 10^{-3}$ \\
PM5006(RP4) & P29nal-r & Nal K & $1 \times 10^{-3}$ \\
P29nal-r(RP4) & J62str-r & S K & $3 \times 10^{-3}$ \\
& * Symbols as in Table 1.
\end{tabular}

action on strains of $E$. coli with resident plasmids of the other groups tested (see Table 1; results not shown). The host range of phage PR4 appeared to be identical but that of phage PRR1 was confined to strains carrying the P-1 plasmids RP4, R68.45 or R772 (Table 2). Although the phage suspensions were made on J62-1 carrying R772, a presumed P-1 plasmid (see above and Discussion), the efficiency of plating (not shown) was slightly higher on J53-1 carrying the W group plasmid RSa. Only a few other combinations of bacterial host, plasmid and phage were tested (Table 3). The remarkable feature was that although undiluted suspensions (about $1 \times 10^{9}$ p.f.u. $\mathrm{ml}^{-1}$ ) of all three phages formed areas of partial clearing when spotted on lawns of PM5006nal-r(R772), PM5006(RP4) or P29nal-r(RP4), plaque formation was never detected. The areas of clearing were specific in the sense that no such effect was detected on isogenic organisms lacking the plasmids 


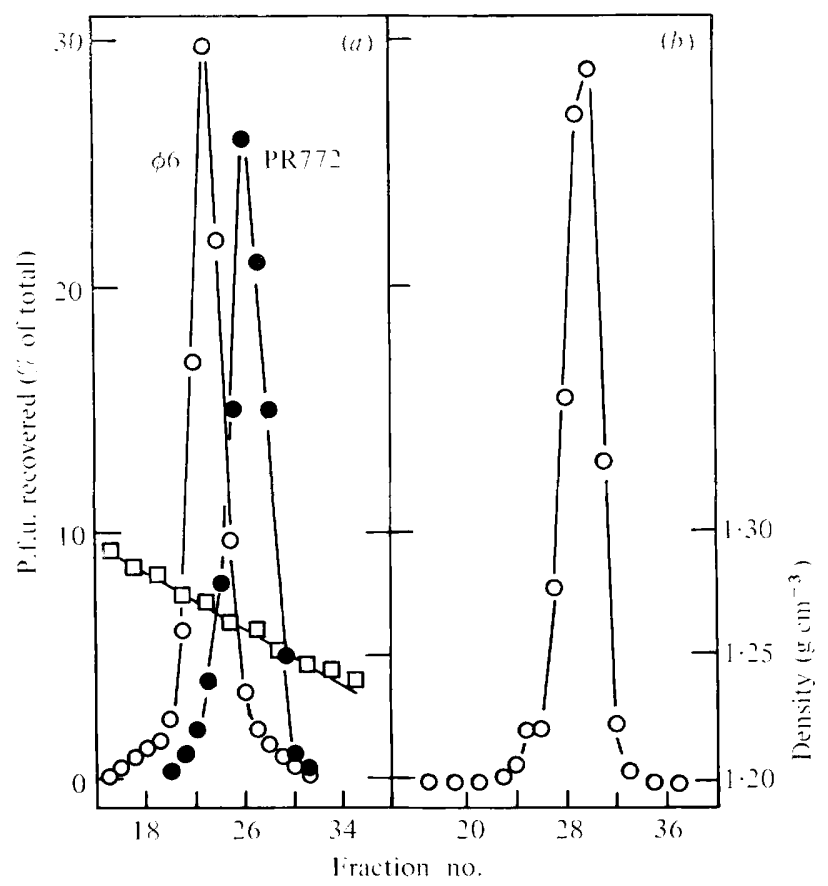

Fig. 8. (a) Cosedimentation to equilibrium of $\mathrm{PR} 772$ and $\phi 6$ in $\mathrm{CsCl}$. $\mathrm{CsCl}$ was added to the mixture in TNTC buffer to give a mean density of $1.26 \mathrm{~g} \mathrm{~cm}^{-3}$. Centrifugation was at $90000 \mathrm{~g}$ for $48 \mathrm{~h}$ at $4{ }^{\circ} \mathrm{C}$ in an SW65 rotor. Fractions were collected dropwise from the bottom of the tube. Samples of $20 \mu \mathrm{l}$ were taken from alternate fractions for refractometrical measurements and all fractions were diluted serially. Spot titrations were followed by duplicate plating on strains J62-1(R772) and HB10Y of the fractions shown. $\bigcirc$, Phage $\phi 6$; - , phage PR772; $\square$, density.

(b) Cosedimentation to equilibrium of PR4 and PR772 in $\mathrm{CsCl}$. Conditions were as in (a). Strain J62-1(R772) was used as indicator.

(Table 3). In other experiments phage adsorption to these strains was slight and often doubtful and phage multiplication in liquid medium could not be demonstrated (Table 3 ). These strains could, however, transfer plasmids R772 or RP4 to other recipients (Table 4).

Adsorption of phage PR772 to plasmid-specific pili. In preparations of J62-1(R772) to which phages PRR1 and PR772 had both been added, many tubular rods, with dimensions similar to those described above, were seen with PRR1 adsorbed to their sides and PR772 adsorbed to one tip (Figs 5, 6). With PM5006nal-r(R772) similar structures were not seen. Instead phage PR772 adsorbed to the latter in closely packed virions uniformly distributed over the cell surface (Fig. 7). In these preparations free phage was purely of the hexagonal type. No adsorption of phage PRR1 to this organism could be demonstrated (but see Table 3). In preparations of PR772 added to J53(N3) the phage was distributed over the surface of the organism, much like that seen with PM5006nal-r(R772) preparations. Here again free phage was purely of the hexagonal type and no 'tails' or tubes were seen.

Buoyant density. Phage PR772 was centrifuged together with $\phi 6$ in the same $\mathrm{CsCl}$ gradient, starting with a mean density of $1.26 \mathrm{~g} \mathrm{~cm}^{-3}$ (Fig. $8 \mathrm{a}$ ). Using the relation $\rho^{25}=10 \cdot 2402 \eta_{\mathrm{D}}^{25}-12.6483$ (Bruner \& Vinograd, 1965) and the density of $1.27 \mathrm{~g} \mathrm{~cm}^{-3}$ for $\phi 6$ (Vidaver et al., 1973), a buoyant density of $1.26 \mathrm{~g} \mathrm{~cm}^{-3}$ was obtained for phage PR772.

Phages PR772 and PR4 were also centrifuged together, each at $10^{8}$ p.f.u. $\mathrm{ml}^{-1}$, in one $\mathrm{CsCl}$ gradient. The buoyant densities of these phages were indistinguishable (Fig. $8 b$ ), as expected since the buoyant density of PR4 is $1.265 \mathrm{~g} \mathrm{~cm}^{-3}$ (Bradley \& Rutherford, 1975). 


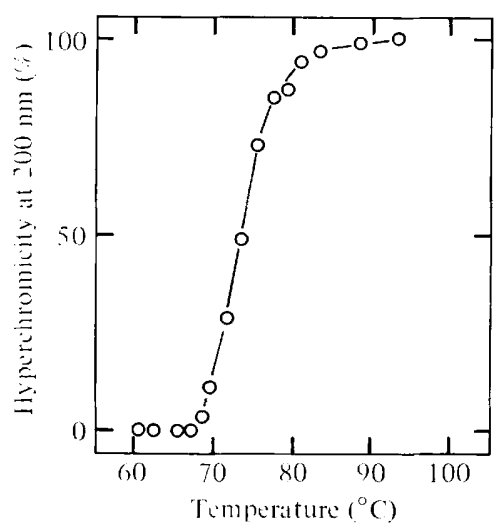

Fig. 9. Melting profile of PR772 DNA obtained by the method of Mandel \& Marmur (1968).

Nucleic acid melting. The melting profile of PR772 DNA is shown in Fig. 9. Escherichia coli DNA was used as a reference standard. Assuming $50 \% \mathrm{G}+\mathrm{C}$ for the E. coli DNA (Marmur \& Doty, 1962), the G+C content of PR772 DNA was calculated from the observed $T_{\mathrm{m}}\left(73 \cdot 6{ }^{\circ} \mathrm{C}\right)$ as $48 \%$.

\section{DIS CUSSION}

Results of incompatibility studies reported here assigned R772 to the P-1 group (Stanisich, 1974; Bradley \& Rutherford, 1975; Shahrabadi et al., 1975; Bryan et al., 1973; Jacoby, 1974; Hedges \& Jacob, 1975) although its incompatibility interactions with R751 are not typical of members of this group. Plasmids RP4, R702 or R1033, for example, interact reciprocally with R751, eliminating and being eliminated by it (Hedges \& Jacob, 1974; Smith et al., 1975). Plasmid R772 eliminates R751 efficiently but is subject to elimination only after a long delay and, in the absence of selection, strains carrying both plasmids segregate far more $\mathrm{R} 751^{-}$progeny than R772- progeny. Such asymmetric segregation patterns have been previously reported for some pairs of incompatible plasmids but this is the first instance involving R751.

The diameter of the head of phage PR772 is smaller (53 nm versus $65 \mathrm{~nm}$ ) than that of phages PR4 and PRD1 (Bradley \& Cohen, 1977; Bradley, 1976; Olsen et al., 1974) and it does not have the elusive tail (Stanisich, 1974; Bradley, 1974; Olsen et al., 1974) which the last two phages possess (Bradley \& Cohen, 1977; Bradley \& Rutherford, 1975). The chloroform sensitivity of PR772 together with a buoyant density of $1.26 \mathrm{~g} \mathrm{~cm}^{-3}$ suggest that the inner membrane of the phage (Fig. 2) contains lipid (Bradley \& Rutherford, 1975).

The hollow tubular rods attached to a small proportion of particles could be misinterpreted as tails. However, their diameter was similar to that of sex pili coded for by incompatibility group P-1 plasmids (Bradley, 1974, 1975) and phage PRR1 adsorbed to the sides of these structures (Figs 5,6). The fact that various lengths of these structures were found attached to the particles (Figs 3,4) also suggested that the former were broken pili to which the phage was attached at one end. This view was strengthened by the fact that with phage PR772.J53(N3) added to J53(N3), no phage 'tails' were observed. Plasmids of the N group are thought not to code for 'conventional' sex pili (see below).

The presence of large numbers of phage attached to the periphery of PM5006nal-r(R772) was puzzling since no particles in these preparations were attached to free pili. It could be argued that the particles had been drawn to the surface of the cell by retractile pili (Bradley, 1972a, b, 1973, 1976). The situation is reminiscent of that for phages PRD1 (Olsen et al., 
1974) and PR4 (Bradley \& Rutherford, 1975; Bradley, 1974) before they were found to attach to the tips of pili (Bradley, 1976; Bradley \& Cohen, 1977). If it is further postulated that sex pili must attain a certain mean length before retraction (or sometimes shedding) and that these events are strongly host-dependent, the hypothesis could accommodate most features of the odd behaviour of PM5006nal-r(R772). Another explanation could be that R772 codes for pili in J62-1 but that in PM5006nal-r the pili are only expressed as somatic receptors (Bradley, 1974).

There are precedents for the behaviour of PM5006: $\mathrm{N}$ incompatibility group plasmids may not code for structures resembling conventional sex pili and the specific phage IKe apparently adsorbs directly to the cell surface (Brodt et al., 1974; Dennison \& Baumberg, $1975 a, b)$ although the phenomenon of pilus retraction, mentioned above, appears to have been ignored. Baumberg \& Dennison (1975) and Morgan \& Kaplan (1977) found that F pili are poorly expressed in $P$. mirabilis. Also $P$. morganii strain 2815 carrying $\mathrm{N}$ group plasmids does not propagate phage IKe although $\mathrm{N}$-linked IKe sensitivity is transferrable from the strain (Dennison \& Baumberg, 1975a). The phenomenon of plasmid-specific phage not forming plaques on certain strains of organisms harbouring the plasmid has also been noted by Olsen \& Thomas (1973) and Olsen et al. (1974). In the cases presented here the refractory strains were capable of transferring their plasmids (Table 4). Evidently the maintenance of an $\mathbf{R}$ plasmid permitting the observed degree of donor activity in these strains was not sufficient in itself to allow phage development. In this regard, a nice distinction can be made between the incompatibility group P-1 plasmids RP4 and R772: in Providence strain P29nal-r only the latter allows plaque formation by phage PR772.

The low neutralization constants of antisera prepared with phage PR772 were unsatisfactory for demonstrating serological relatedness between phages, but low $\mathrm{K}$ values are a feature of this type of phage (Franklin, 1974; Stanisich, 1974; Bradley \& Rutherford, 1975). Nevertheless all three sera neutralized phage PR4 at much lower efficiencies than homologous phage and the two phages may possibly be only distantly related antigenically. One implication may be that tips of pili to which the phages adsorb possess more than one kind of adsorption site. This may be possible, as tips of $F$ pili have at least three similar sites for adsorption of $\mathrm{fl}$ phage (Caro \& Schnös, 1966).

Plasmids of compatibility groups $\mathrm{P}, \mathrm{N}$ and $\mathrm{W}$ determine production of receptors for phages PR772 and PR4. DNA sequences of these plasmid groups show no homology by hydroxyapatite or single-strand S1 nuclease methods (Falkow et al., 1974) although it is unlikely that similarity limited to one gene (e.g. that for a pilus subunit) could be reliably detected by these methods. Pili determined by $\mathrm{P}$ and $\mathrm{W}$ plasmids are distinct morphologically and unrelated serologically (Bradley, 1975, 1976; Bradley \& Cohen, 1977) and the transfer apparatus determined by $\mathrm{N}$ pili cannot be detected by the techniques which have been used to characterize $\mathrm{W}$ and $\mathrm{P}$ pili. Yet, the phages adsorb to the tips of $\mathrm{P}$ and $\mathrm{W}$ pili and presumably to analogous sites on the hypothetical $\mathrm{N}$ pili.

We propose that (as implied by the morphological and serological differences of the pili and by the unrelatedness of the DNA sequences) the transfer apparatus determined by $P$, $\mathrm{W}$ and $\mathrm{N}$ pili may be phylogenetically unrelated but that, presumably due to the need to bind to a common component in the cell walls of recipient bacteria, the pilus tips have undergone convergent evolution leading to stereospecific similarities great enough to permit them to act as common receptors for tip-binding phages. There would be no comparable selective forces leading to convergence of other aspects of pilus structure and thus phages (such as PRR1) binding to the sides of pili have narrow host specificities adsorbing only on to the pili coded by plasmids with closely related transfer apparatus.

This is not the only example of evolutionary convergence of pilus tips; at least two other cases seem well established. Grindley et al. (1973) showed that phage If1 (Meynell \& Lawn, 1968; Meynell, 1972) which adsorbs to the tips of I pili can also be bound by cells carrying the plasmid TP114 which has no detectable DNA homology with the I group plasmids. 
Also F pili act as receptors for RNA phages (which adsorb to the sides) and for filamentous DNA phages (which adsorb to the pilus tips). The former phages are absolutely specific, binding only to pili of F-like plasmids, whilst phages of the latter group adsorb to serologically unrelated pili produced by a variety of other plasmid types (Bradley, 1977).

We therefore conclude that, in these several cases, groups of unrelated transmissible plasmids have undergone evolutionary convergence of the stereospecificity of the pilus tips, presumably as a result of the requirement for recognition of common cell wall receptors for conjugation and, as a consequence, provide common receptors for phages which bind to the pilus tips.

\section{REFERENCES}

Adams, M. H. (1956). Methods of study of bacterial viruses. Methods in Medical Research 2, 1-73.

Baumberg, S. \& Dennison, S. (1975). Variation in expression of sex factor genes in the ProteusProvidencia group relative to Escherichia coli. Journal of Bacteriology 123, 278-286.

Bradley, D. E. (1972a). Shortening of Pseudomonas aeruginosa pili after RNA-phage adsorption. Journal of General Microbiology 72, 303-319.

BRADLEY, D. E. $(1972 b)$. Evidence for the retraction of Pseudomonas aeruginosa RNA phage pili. Biochemical and Biophysical Research Communications 47, 142-149.

BRADley, D.E. (1973). The adsorption of the Pseudomonas aeruginosa filamentous bacteriophage Pf to its host. Canadian Journal of Microbiology 19, 623-631.

Bradley, D. E. (1974). Adsorption of bacteriophages specific for Pseudomonas aeruginosa $\mathrm{R}$ factors RP1 and R1822. Biochemical and Biophysical Research Communications 57, 893900.

Bradley, D.E. (1975). The occurrence of pili associated with a plasmid of the W compatibility group. Biochemical and Biophysical Research Communications 64, 918-925.

BradLEy, D. E. (1976). Adsorption of the R-specific bacteriophage PR4 to pili determined by a drug resistance plasmid of the $\mathrm{W}$ compatibility group. Journal of General Microbiology 95, 181-185.

Bradley, D.E. (1977). Characterization of pili determined by drug resistance plasmids $R 711 \mathrm{~b}$ and R778b. Journal of General Microbiology 102, 349-363.

Bradley, D. E. \& Cohen, D. R. (1977). Adsorption of lipid-containing bacteriophages PR4 and PRD1 to pili determined by a P-1 incompatibility group plasmid. Journal of General Microbiology 98, 619-623.

Bradley, D.E. \& Rutherford, E. L. (1975). Basic characterization of lipid-containing bacteriophage specific for plasmids of the $\mathrm{P}, \mathrm{N}$, and W compatibility groups. Canadian Journal of Microbiology 21, 152-163.

Brodt, P., Leggett, F. \& Iyer, R. (1974). Absence of a pilus receptor for filamentous phage IKe. Nature, London 249, 856-858.

Bruner, R. \& Vinograd, J. (1965). The evaluation of standard sedimentation coefficients of sodium RNA and sodium DNA from sedimentation velocity data in concentrated $\mathrm{NaCl}$ and $\mathrm{CsCl}$ solutions. Biochimica et biophysica acta 108, 18 29.
Bryan, L. E., Semaka, S. D., Van den Elzen, H. M., Kinnear, J.E. \& Whitehouse, R. L. S. (1973). Characteristics of R931 and other Pseudomonas aeruginosa R factors. Antimicrobial Agents and Chemotherapy 3, 625-637.

Caro, L. G. \& SCHNös, M. (1966). The attachment of the male-specific bacteriophage $F 1$ to sensitive strains of Escherichia coli. Proceedings of the National Academy of Sciences of the United States of America 56, 126-132.

Clowes, R. C. \& Hayes, W. (1968). Experiments in Microbial Genetics. Oxford and Edinburgh: Blackwell Scientific Publications.

Coetzee, J. N. (1966). Transduction in Proteus morganii. Nature, London 210, 220.

Coetzee, J. N. (1974). High frequency transduction of kanamycin resistance in Proteus mirabilis. Journal of General Microbiology 84, 285-296.

Coetzee, J. N. (1978). Mobilization of the Proteus mirabilis chromosome by $\mathbf{R}$ plasmid $\mathbf{R} 772$. Journal of General Microbiology 108, 103-109.

Coetzee, J. N. \& Smit, J. A. (1970). Properties of Proteus mirabilis phage 13vir. Journal of General Virology 9, 247-249.

Coetzee, J. N., Smit, J. A. \& Prozesky, O. W. (1966). Properties of Providence and Proteus morganii transducing phages. Journal of General Microbiology 44, 167-176.

Coetzee, J. N., Datta, N. \& Hedges, R. W. (1972). $\mathrm{R}$ factors from Proteus rettgeri. Journal of General Microbiology 72, 543-552.

Coetzee, J. N., Krizsanovich-Williams, K. \& Williams, J. A. (1977). Cotransduction of morganocinogenic plasmid 174 and $\mathrm{R}$ factor R772. Journal of General Microbiology 100, 299-308.

DAT'TA, N. \& Hedges, R. W. (1972). Host ranges of $\mathrm{R}$ factors. Journal of General Microbiology 70 , $453-460$.

Datta, N., Hedges, R. W., Shaw, E. J., Sykes, R. P. \& Richmond, M. H. (1971). Properties of an $\mathbf{R}$ factor from Pseudomonas aeruginosa. Journal of Bacteriology 108, 1244-1249.

Dennison, S. \& BaumberG, S. (1975a). Unusual characteristics of the receptor for the $\mathrm{N}$ sex factor-specific filamentous phage IKe. Genetical Research 25, 275-284.

Dennison, S. \& Baumberg, S. (1975b). Conjugational behaviour of $\mathrm{N}$ plasmids in Escherichia coli K12. Molecular and General Genetics 138, 323-331.

Falkow, S., Guerry, P., Hedges, R. W. \& Datta, N. (1974). Polynucleotide sequence relationships among plasmids of the I compatibility complex. Journal of General Microbiology 85, 65-76. 
FrankLIN, R. M. (1974). Structure and synthesis of bacteriophage PM2, with particular emphasis on the viral lipid bilayer. Current Topics in Microbiology and Immunology 68, 107-159.

Grindley, N. D. F., Humphreys, G. O. \& Andfrson, E.S. (1973). Molecular studies of R factor compatibility groups. Journal of Bacteriology 115 , 387-398

HaAs, D. \& Holloway, B. W. (1976). R factor variants with enhanced sex factor activity in Pseudomonas aeruginosa. Molecular and General Genetics 144, 243-251.

Hedges, R. W. (1972). Phenotypic characterization of $f^{-} \mathbf{R}$ factors determining the restriction and modification of $h s p$ II specificity. Molecular and General Genetics 115, 225-233.

Hedges, R. W. (1975). R factors from Proteus mirabilis and $P$. vulgaris. Journal of General Microbiology 87, 301-311.

Hedges, R. W. \& Datta, N. (1971). $f^{- \text {R factors }}$ giving chloramphenicol resistance. Nature, London 234, $220-221$.

Hedges, R. W. \& Jacob, A. E. (1974). Transposition of ampicillin resistance from RP4 to other replicons. Molecular and General Genetics 132, $31-40$.

Hedges, R. W. \& JACOB, A. E. (1975). Mobilization of plasmid-borne drug resistance determinants for transfer from Pseudomonas aeruginosa to Escherichia coli. Molecular and General Genetics 140, 69-79.

JACOBY, G. A. (1974). Properties of R plasmids determining gentamicin resistance by acetylation in Pseudomonas aeruginosa. Antimicrobial Agents and Chemotherapy 6, 239-252.

Jobanputra, R. A. \& Datta, N. (1974). Trimethoprim $\mathrm{R}$ factors in enterobacteria from clinical specimens. Journal of Medical Microbiology 7 , 169-177.

Khatoon, H., Iyer, R. V. \& Iyer, V. N. (1972). A new filamentous bacteriophage with sex-factor specificity. Virology 48, 145-155.

Mandel, M. \& MARmur, J. (1968). Use of ultraviolet absorbance-temperature profile for determining the guanine plus cytosine content of DNA. Methods in Enzymology 12, 195-206.

MARMur, J. \& Doty, P. (1962). Determination of base composition of deoxyribonucleic acid from its thermal denaturation temperature. Journal of Molecular Biology 5, 109-118.

Meynell, E. \& CoOKe, M. (1969). Repressorminus and operator-constitutive de-repressed mutants of F-like $\mathrm{R}$ factors: their effect on chromosomal transfer by $\mathrm{HfC}$. Genetical Research 14, 309-313.

Meynell, E. \& DatTA, N. (1967). Mutant drug resistance factors of high transmissibility. Nature, London 214, 885-887.

Meynell, G. G. (1972). Bacterial Plasmids. London: MacMillan.

Meynell, G. G. \& LAWN, A. M. (1968). Filamentous phages specific for the I sex factor. Nature, London 217, 1184-1186.

Morgan, E. A. \& Kaplan, S. (1977). Expression and stability of Escherichia coli $\mathrm{F}$-prime factors in Proteus mirabilis. Molecular and General Genetics 151, 41-47.

Olsen, R. H. \& Thomas, D. D. (1973). Characteristics and purification of PRR1, an RNA phage specific for the broad host range Pseudomonas R1 882 drug resistance plasmid. Journal of Virology 12, 1560-1567.

Olsen, R. H., Siak, J.-S. \& GRAY, R. H. (1974). Characteristics of PRD1, a plasmid-dependent broad host range DNA bacteriophage. Journal of Virology 14, 689-699.

Sands, J. A., Cupp, J., Keith, A. \& Snipes, W. (1974). Temperature sensitivity of the assembly process of the enveloped bacteriophage $\phi 6$. Biochimica et biophysica acta 373, 277-285.

Shahrabadi, M.S., Bryan, L.E. \& VAN DEN ELZEN, H. M. (1975). Further properties of P-2 R-factors of Pseudomonas aeruginosa and their relationship to other plasmid groups. Canadian Journal of Microbiology 21, 592-605.

Smith, D. I., Gomez Lus, R., Rubio Calvo, M. C., DAtTA, N., JACOB, A. E. \& Hedges, R. W. (1975). Third type of plasmid conferring gentamicin resistance in Pseudomonas aeruginosa. Antimicrobial Agents and Chemotherapy 8, 227230.

Stanisich, V. A. (1974). The properties and host range of male-specific bacteriophages of Pseudomonas aeruginosa. Journal of General Microbiology 84, 332-342.

Vidaver, A. K., Koski, R. K. \& Van Etten, J. L. (1973). Bacteriophage $\phi 6$ : a lipid-containing virus of Pseudomonas phaseolicola. Journal of Virology 11, 799-805.

WiLLIAMS, J. A. (1977). Mobilization of morganocin 174 plasmid and kinetics of morganocin production in Proteus and Escherichia coli hosts. Antimicrobial Agents and Chemotherapy 11, 514-520. 